\title{
PREFIXOS, RECURSIVIDADE E A ESTRUTURA DO SINTAGMA VERBAL
}

\author{
Alessandro Boechat de MEDEIROS ${ }^{1}$
}

Resumo: O presente artigo procura explicar a distribuição dos prefixos re- e des-, as relações semânticas e posicionais entre eles quando co-ocorrem e suas relações com a estrutura do sintagma verbal. As propostas apresentadas mostram evidências de que uma decomposição sintática de estruturas de eventos associadas aos sintagmas verbais permite explicações naturais para as propriedades discutidas nas seções iniciais do artigo. Ao final, discute-se brevemente a participação dos prefixos recursivos na definição de significados especiais de raízes.

Palavras-chave: Prefixos. Estrutura de eventos. Raízes. Morfemas categorizadores. Morfologia Distribuída.

\section{Introdução}

Este artigo trata dos prefixos re- e des- no ambiente verbal. Investiga as relações possíveis entre eles, sua relação com a estrutura sintática do sintagma verbal, com teorias de estrutura argumental e com teorias de fases dentro de palavras.

Nas páginas a seguir, buscarei mostrar que uma abordagem baseada em representações sintáticas para as estruturas de eventos associadas aos sintagmas verbais, combinada a uma abordagem (pelos menos parcialmente) baseada em escopo sintático para os prefixos aqui sob análise (SPORTICHE, 2012; ALEXIADOU et alii, 2015; CARDINATLETTI, 2003; MARANTZ, 2007; STECHOW, 1997²; MEDEIROS, 2010; MEDEIROS, 2012, entre outros) explicam diversas de suas propriedades. Entender, pois, o comportamento desses prefixos pode, entre outras coisas, contribuir para o estabelecimento de teorias de estrutura argumental (de eventos) dos verbos que os licenciam (e dos que não os licenciam). Em particular, argumentarei

\footnotetext{
${ }^{1}$ Professor Adjunto do Departamento de Linguística e Filologia da Universidade Federal do Rio de Janeiro. Email: alboechat@gmail.com

${ }^{2} \mathrm{O}$ trabalho de Stechow citado não trata de prefixos, mas do modificador adverbial wieder no alemão. Coloqueio nessa lista de referências porque apresenta soluções para problemas relacionados à distribuição e interpretação desse advérbio usando a ideia de escopo sintático, e adota um tipo de decomposição sintática do sintagma verbal para explicar a leitura restitutiva do advérbio. Falarei da proposta brevemente mais adiante.
} 
em favor de uma estrutura sintagmática verbal com três camadas: a do sintagma raiz (ou alguma estrutura de predicação interna, envolvendo um predicador que será o radical do verbo e o complemento desse verbo), à qual pode anexar-se o prefixo des-, a do sintagma verbal $(v \mathrm{P})$, à qual pode anexar-se o prefixo re-, e a do sintagma encabeçado pelo núcleo Voz, fora do escopo dos dois prefixos, que projeta uma posição para o argumento externo do verbo.

Entre as muitas propriedades dos prefixos aqui estudados, uma bem pouco discutida na literatura receberá um olhar especial: a recursividade. Podemos ter mais de uma ocorrência dos prefixos re- e des- em um determinado verbo, e todas as ocorrências serão (re)aplicações de uma mesma regra de interpretação ao resultado de sua aplicação imediatamente anterior. Os exemplos abaixo o mostram:

(1) a. João desdesmarcou o encontro de amigos na sua casa.

b. Pedro rerreavaliou os documentos apresentados pelo advogado.

Em (1a), a segunda ocorrência do prefixo inverte ou nega o estado resultante de inversão ou negação anterior, decorrente da primeira ocorrência do prefixo. A sentença em (1b) denota repetição (segunda ocorrência do prefixo) de uma avaliação que já havia sido repetida (primeira ocorrência do prefixo).

Note-se que isso não é uma propriedade de qualquer prefixo. Por exemplo, os prefixos en- em engavetar, es- em esfarelar ou $a$ - em acarpetar não podem ser acrescidos a estruturas que já os tenham, como os exemplos abaixo o mostram:

(2) a. *João enengavetou os documentos.

b. *Mário esacarpetou seu escritório.

A presença de prefixos como re- e des-, contudo, não é proibida sobre formações com os prefixos encontrados em (2):

(3) a. Mário reacapertou a sala.

c. O juiz redesengavetou o processo.

De fato, parece que temos pelo menos dois tipos de prefixos em verbos: os que são "adverbiais", exemplificados em (1), e os que criam estrutura argumental a partir de bases nominais, exemplificados em $(2)^{3}$.

Veremos, mais adiante, que uma segunda ocorrência dos prefixos re- e des- nunca é idiomática (ou, por outros termos, um prefixo recursivo parece estar ligado à definição de

\footnotetext{
${ }^{3}$ Há muita discussão na literatura a respeito da natureza derivacional ou composicional da prefixação em português. Não pretendo, contudo, tratar desse assunto neste artigo, ainda que reconheça sua importância. Remeto o leitor interessado aos trabalhos de Câmara Jr. (que, em seu Dicionário de Linguística e Gramática, define alguns tipos de prefixação como uma forma de composição - ver verbetes: PREFIXO e COMPOSIÇÃO) e Gonçalves (2012), que faz, entre outras coisas, uma interessante revisão da questão na literatura.
} 
domínio de significado especial para uma raiz), e isso tem implicações teóricas interessantes, que discutirei no final do artigo.

O objetivo deste trabalho é reunir alguns fatos a respeito dos prefixos $r e$-e des-e propor uma análise que dê conta desses fatos. O referencial teórico adotado será o da Morfologia Distribuída (HALLE; MARANTZ, 1993), particularmente por assumir que as "palavras" possuem estruturas de constituintes, o que favorece abordagens baseadas em escopo sintático, como a que defendo aqui. O texto tem a seguinte organização. Nas próximas duas seções apresento alguns dados sobre os prefixos que pretendo analisar. Parte dessa discussão já foi feita em outros artigos (MEDEIROS, 2010; MEDEIROS, 2012), mas fatos novos e mesmo a contestação empírica de conclusões contidas nos trabalhos citados serão apresentados. Em seguida, apresento uma proposta estrutural - uma estrutura de eventos sintaticamente representada a cujos nós os prefixos podem anexar-se - para lidar com as distribuições dos prefixos e seus significados e discuto a relação dessas propostas com a ideia de que existem fases (CHOMSKY, 2001) dentro de palavras (MARANTZ, 2001; MARANTZ, 2013; EMBICK, 2010). O texto termina com algumas questões ainda abertas à investigação.

\section{Algumas propriedades dos prefixos recursivos re- e des-}

Uma parte da literatura (por exemplo, SILVA; MIOTO, 2009) defende que o prefixo des- denota algum tipo de inversão de processo quando ocorre em verbos e negação quando ocorre em adjetivos (ou seja, o léxico disponibiliza duas entradas para o prefixo). Ribeiro (2014) defende que o prefixo define uma inversão de direcionamento, representado na estrutura léxicoconceitual dos verbos aos quais se afixa ${ }^{4}$. O Dicionário Houaiss Eletrônico (HOUAISS, 2009) menciona somente oposição, negação ou falta, com exemplos de classes nominais (adjetivos e substantivos, como desleal ou desamor), separação em formações parassintéticas (como “desossar”) e intensificação em formas como desinfeliz.

Concentrando-me nos verbos, a presença de des- parece não estar trivialmente relacionada à inversão de processo, uma vez que isso implicaria a pressuposição do processo invertido, o que nem sempre é verdadeiro (MEDEIROS, 2010). Veja-se o exemplo a seguir:

\footnotetext{
${ }^{4}$ Por exemplo, em sentenças como "o lago congelou", encontramos a seguinte estrutura léxico-conceitual: [Event $\mathrm{GO}_{\text {Circ }}\left(\left[\right.\right.$ Thing $\left.\mathrm{LAGO}_{\mathrm{i}}\right]$, [Path $\mathrm{TO}_{\text {Circ }}\left[\right.$ State $\mathrm{BE}_{\text {Ident }}\left(\left[\right.\right.$ Thing $\left.\mathrm{X}_{\mathrm{i}}\right]$, [Place $\mathrm{AT}_{\text {Ident }}([$ Property CONGELADO $\left.\left.\left.\left.\left.])\right]\right)\right]\right)\right]$; já na frase "o lago descongelou" temos o seguinte: [Event $\mathrm{GO}_{\text {Circ }}\left(\left[\right.\right.$ Thing $\left.\mathrm{LAGO}_{\mathrm{i}}\right]$, [Path $\mathrm{FROM}_{\text {Circ }}$ [State $\mathrm{BE}_{\text {Ident }}\left(\left[{ }_{\text {Thing }} \mathrm{X}_{\mathrm{i}}\right]\right.$, [Place $\mathrm{AT}_{\text {Ident }}$ ([Property CONGELADO])])])]. Vê-se que o direcionamento é trocado pela anexação do prefixo com a substituição do predicado locacional dentro da estrutura léxico-conceitual do item de base (o verbo "congelar").
} 
(4) Infelizmente os produtos químicos que vocês espalharam dentro da estufa descoloriram as pétalas das flores.

É improvável que as pétalas tenham sido um dia coloridas. Então, como se inverte um processo que nunca ocorreu, como propõem Silva e Mioto (2009)? A proposta de Ribeiro (2014) daria conta de (4) sem dificuldades, mas não se aplica, como reconhecido pelo próprio autor, nem às classes nominais que licenciam o prefixo (onde esse mais claramente assume o significado de negação, como em desleal ou desânimo) nem em alguns verbos em que não há mudança de estado (ver (7) abaixo), como é o caso de desrespeitar e desaconselhar ${ }^{5}$. Ademais, não é claro para mim como lidar, baseado nessa proposta, com a recursividade do prefixo desno verbo. Se, na estrutura léxico-conceitual do verbo prefixado, o prefixo simplesmente substitui o predicado TO por FROM (ver nota 4), não é recursivo; se a função dele é inverter o direcionamento do predicado locacional (trocando TO por FROM ou FROM por TO, quando for o caso), não há diferença entre verbos com duas (ou um número par de) ocorrências do prefixo e verbos sem o prefixo, o que é uma consequência bastante indesejável, a meu ver.

No exemplo (4), o que parece acontecer é que se pressupõe que o complemento do verbo estivesse, de partida, num estado que é o alvo do processo de colorir (ter uma determinada cor, cores ou tonalidades dessas cores - o que não quer dizer, claro está, que tal estado só possa ser uma decorrência de tal processo). O prefixo des- em descolorir não inverte um processo ou seu direcionamento, mas diz que, ao final do processo denotado pelo verbo prefixado, o objeto atinge um estado que é a negação do estado pressuposto ${ }^{6}$. Note-se que esta é uma das acepções do particípio passado do verbo colorir: colorido veicula tanto a interpretação de resultado irreversível de determinado evento (o estado de determinada coisa ter sido colorida, chamado por PARSONS, 1990 e KRATZER, 1999 de estado resultante) como a interpretação de estado que pode ser invertido, o estado alvo de Parsons (1990) e Kratzer (2000). Tipicamente, os verbos cujos particípios não excluem a interpretação de estado alvo - compatíveis, segundo

\footnotetext{
${ }^{5}$ Ribeiro (2014) aponta um problema na ideia de que o prefixo des- veicule negação em verbos: em frases como "o lago descongelou um pouco", não é verdade que o lago atingiu o estado não-congelado ao final do processo. Contudo, o que pode estar ocorrendo, nesse caso, é que uma parte do volume da água do lago passou ao estado não-congelado, e essa situação seria a descrita pela frase. Portanto, "um pouco" pode indicar algo sobre o volume de água que passou a estar não-congelado, não necessariamente sobre um grau de (des)congelamento. Mais problemáticas são sentenças como "a roda da bicicleta desentortou um pouco", sentenças que envolvem um adjetivo de grau na base do verbo. Aqui, uma explicação possível seria a seguinte: o adjetivo de base pode veicular, a depender dos advérbios presentes, não só um estado, mas um ponto máximo da escala associada a esse estado considerando a situação em que o verbo é usado, e o prefixo nega o estado no grau em questão.

${ }^{6}$ Estou tratando como aproblemática a afirmação de que uma determinada entidade y está num estado Y que é a negação de um estado X: dizer que y não está no estado X (ou está no estado Y que é um não-X) parece pouco informativo a não ser que previamente y estivesse no estado $\mathrm{X}$ ou que houvesse uma expectativa (por parte do ouvinte) de que y estivesse no estado $\mathrm{X}$ antes de se afirmar o contrário. Talvez aí esteja a origem da pressuposição introduzida pelo prefixo, mas não vou desenvolver essas ideias aqui.
} 
Kratzer (2000), com o advérbio ainda - aceitam o prefixo (ver também OLIVEIRA, 2004, para uma constatação relacionada).

Acrescente-se que existem casos em que o particípio do verbo não denota um estado alvo, mas o verbo é derivado de um adjetivo que descreve tal estado. Veja-se (5) a seguir:

(5) a. O desmatamento desfertilizou o solo de parte do estado.

b. Contínuas crises financeiras desigualaram juridicamente as classes.

Aqui, o pressuposto é de que o solo era fértil antes do desmatamento. O mesmo vale para as classes sociais antes das contínuas crises financeiras: eram iguais.

Já os verbos cujos particípios denotam exclusivamente estados irreversíveis, ou que não derivam de certos tipos de adjetivos, tipicamente não aceitam o prefixo ou o aceitam muito marginalmente; do mesmo modo, verbos que denotam atividades (OLIVEIRA, 2004; MEDEIROS, 2010), mas podem compor com seus complementos um accomplishment, a princípio sem envolver um estado (alvo) atingido pelo complemento, como dançar, cantar, correr, andar, caminhar, ler etc. Os exemplos a seguir o mostram.

(6) a. ?*João descantou aquela famosa ária da ópera Fidelio.

b. ??Mário descaminhou o quilômetro que liga minha casa ao terreno baldio.

c. ??Valéria desleu aquele livro de crítica cinematográfica.

d. ??Gauss desprovou o Teorema de Fermat.

O prefixo des-, contudo, ocorre em alguns verbos que não se enquadram na descrição apresentada acima: os verbos em (7) a seguir não denotam processos cuja culminação envolve um estado inversível atingido pelo complemento, e o licenciamento do prefixo não depende claramente de um estado pressuposto.

(7) a. Maria desrespeitou seu pai hoje cedo.

b. A empresa descumpriu o contrato e foi penalizada.

c. O advogado desconhecia o destino de seu cliente.

d. O pesquisador desconsiderou os dados obtidos no segundo teste.

e. Pedro desaconselhou seu filho a passar a noite naquele hotel.

f. O menino desobedeceu às instruções de segurança.

Note-se, ainda, que o significado do prefixo des- em (7) está mais próximo de um simples não do que no exemplo (4):

(8) Maria desrespeitou seu pai hoje cedo $\approx$ Maria não respeitou seu pai hoje cedo.

(9) Os produtos descoloriram as pétalas $\neq$ Os produtos não coloriram as pétalas.

Apesar de o uso do prefixo não ser aparentemente produtivo em verbos do tipo encontrado em (7), os exemplos servem para a condução da seguinte discussão, que considero 
relevante. Atentemos para a relação entre a quantificação do complemento e a assumida negação veiculada pelo prefixo. Em frases como (10) abaixo, a quantificação universal tem escopo sobre a negação denotada pelo prefixo, nunca o contrário.

(10) Maria desrespeitou todos os idosos.

Em (10), a única leitura próxima possível é: para todo idoso x, Maria não respeitou x. A interpretação não é verdade que para todo idoso x Maria respeitou $x$ não é possível. No entanto, para a frase como (11), as duas leituras são possíveis (preferencialmente a última).

(11) Maria não respeitou todos os idosos.

Os exemplos a seguir, que envolvem um complemento oracional, mostram que o prefixo des- veicula uma negação cujo escopo continua excluindo a quantificação do complemento direto e, curiosamente, incidindo sobre a oração infinitiva. Comparem-se (12a) e (12b) abaixo:

(12) a. Pedro desaconselhou todos os meninos a cantar na festa de formatura.

b. Pedro não aconselhou todos os meninos a cantar na festa de formatura.

A sentença (12b) é verdadeira em pelo menos dois tipos de situações: (i) Pedro não deu o referido conselho a todos os meninos (aconselhou somente alguns, talvez); (ii) Pedro aconselhou todos os meninos a não cantar na festa. O significado da sentença em (12a) só é razoavelmente compatível com o segundo cenário.

Agora comparemos os exemplos discutidos acima com a seguinte sentença:

(13) O João desmontou todas as máquinas de lavar.

Ao final do processo denotado pelo predicado, para toda máquina de lavar $x$, não é verdade que $x$ esteja montada. Assumindo que o prefixo denota uma negação mesmo em sentenças como (9) acima, como tenho feito, mas uma negação sobre o estado alvo do evento, se a negação veiculada por ele tivesse escopo sobre a quantificação do complemento do verbo, teríamos que, ao final do processo de “desmontar todas as máquinas de lavar”, não seria verdade que para toda máquina de lavar $x, x$ ainda estivesse montada. Mas se a frase acima tivesse essa interpretação, seria verdadeira num cenário em que ainda existissem máquinas de lavar montadas depois de o processo ter-se concluído, o que não é o caso.

Portanto, as mesmas relações de escopo entre quantificação do complemento e a negação (supostamente) veiculada pelo prefixo se mantêm em todos os casos. Parece-me que essa propriedade reforça a ideia de que devemos interpretar o prefixo des- como negação, sempre; as propriedades acionais dos verbos envolvidos é que podem causar as diferenças entre (8) e (9).

Por fim, vale notar que, em sentenças como (14) abaixo, o advérbio rapidamente está fora do escopo da negação veiculada pelo prefixo. Aqui, a máquina de lavar atingiu rapidamente 
o estado "não-montado"; nada é dito sobre a rapidez de sua montagem - ou, por outros termos, nada é dito sobre a rapidez do processo que criou o estado pressuposto.

(14) João desmontou rapidamente a máquina de lavar.

Do mesmo modo, em (15a) o advérbio cuidadosamente tem escopo sobre a negação veiculada pelo prefixo. Em sentenças como (15b), a leitura é ambígua, com uma preferência pela leitura em que a negação tem escopo sobre o advérbio.

(15) a. A empresa descumpriu cuidadosamente o contrato.

b. A empresa não cumpriu cuidadosamente o contrato.

Tratarei agora do prefixo re- com o significado dicionarizado de "repetição" (HOUAISS, 2009).

Dos significados listados na entrada correspondente do dicionário, o único que permanece em uma segunda anexação do prefixo é o de repetição: em rerrealçar, por exemplo, o significado atribuído à ocorrência mais encaixada de re- pelo dicionário, "reforço, intensificação", claramente não é o da segunda ocorrência do prefixo.

Contudo, re- não pode ser um simples "repetidor" de processo, pois posso desenterrar e re-enterrar raízes que simplesmente cresceram sob a terra, que jamais foram enterradas antes (MEDEIROS, 2012). Trata-se, pois, nesse caso, de repetição de um estado que é a decorrência do processo descrito pelo verbo prefixado, mas que pode existir independentemente de tal processo (ou seja, as raízes estavam enterradas antes de serem desenterradas, ainda que nunca tenham sido enterradas).

O conceito de repetição não requer direcionamento, telos ou estado atingido. Posso repetir, por exemplo, uma atividade, como em (16):

(16) Pedro correu no calçadão novamente.

Aqui, a atividade não tem ponto final intrínseco, lugar ou estado que seja a sua finalidade ou consequência, mas é possível repeti-la. Entretanto, no exemplo, colocar o prefixo re- no verbo correr, em substituição ao advérbio novamente, mantendo o significado do verbo, produziria, na melhor das hipóteses, uma aceitabilidade marginal. Verbos que denotam eventos sem ponto final intrínseco, como correr, dormir, rir, viajar comportam-se tipicamente como correr em relação ao prefixo. De fato, mesmo quando criamos accomplishments colocando complementos quantificados que estabelecem um ponto final para eventos denotados por alguns desses verbos, a relação de tais verbos com o prefixo continua problemática. Por exemplo, apesar de o predicado correr a maratona denotar um tipo de evento com ponto final, como não 
parece envolver um estado atingido pelo referente de seu complemento ( a maratona $^{7}$, recorrer a maratona tem, na melhor das hipóteses, uma aceitabilidade marginal.

A discussão até aqui poderia induzir o leitor a acreditar que re- e des- teriam a mesma distribuição entre os verbos (como proposto em MEDEIROS, 2012). Entretanto, não é isso que ocorre. Como vimos acima, é possível prefixar verbos como conhecer e respeitar usando des-; mas a prefixação com re-é bem menos aceitável:

(17) ??Maria rerrespeitou seu pai hoje cedo.

(18) \#O deputado reconheceu seus eleitores.

Por outro lado, há muitos verbos que aceitam naturalmente a prefixação com $r e-$, mas menos naturalmente a prefixação com des-. Os itens de (19) abaixo o mostram. Quando o prefixo des- ocorre em alguns dos exemplos abaixo, há, talvez, uma leitura de avaliação negativa sobre o processo descrito pelo verbo de base ${ }^{8}$.

(19) a. Mário releu a obra de Thomas Hardy.

b. ?Mário desleu a obra de Thomas Hardy.

c. Paulo Autran reinterpretou o rei Lear no Teatro João Caetano.

d. ?Paulo Autran desinterpretou o rei Lear no Teatro João Caetano.

e. O matemático redemonstrou o teorema de Pitágoras.

f. ??O matemático desdemonstrou o teorema de Pitágoras.

g. Mário reentrou na sala.

h. ?*Mário desentrou na sala.

Além das diferenças, apontadas acima, de distribuição dos prefixos entre os verbos, há uma assimetria na posição de anexação desses prefixos, quando co-ocorrem. Isso é crucial para uma compreensão do significado do prefixo re-. Na leitura composicional (repetição em re- e negação em des-), re- pode tomar um verbo prefixado com des-, mas o inverso só é aceitável em poucas e duvidosas situações. Veja-se o par em (20) e (21) a seguir:

(20) O governo redesmilitarizou a ação policial no estado.

(21) *O governo desremilitarizou a ação policial no estado.

No exemplo (21), a contribuição do prefixo des-, tomando por base a discussão acima, seria negar um estado modificado (repetido) por re-. A questão é que (21) não é aceitável.

\footnotetext{
${ }^{7}$ Trata-se de fato de complemento do verbo correr. Em consultas ao Google, encontrei inúmeras ocorrências da voz passiva a maratona foi corrida.

${ }^{8}$ Agradeço a Janayna Carvalho por ter chamado minha atenção para essa possível leitura.
} 
Portanto, independentemente do que seja selecionado pelo prefixo, o que ele devolve quando opera sobre a forma não pode ser um estado alvo 9 .

Por fim, é importante mostrar que a discussão sobre o escopo dos operadores que foi feita acima para o prefixo des- vale para o prefixo re-. Tomemos a sentença (22) a seguir:

(22) Pedro reorganizou um arquivo.

Aqui, somente a seguinte leitura está disponível: existe um arquivo x tal que, ao final do processo denotado pelo verbo, novamente x ficou organizado ou foi organizado. A leitura disponível não é novamente existe um arquivo x tal que x ficou organizado. Williams (2006) chama isso de existential closure, propriedade que também vale para o prefixo re- do inglês. Além disso, Williams (2006) nota que advérbios que modificam processos não estão no escopo do prefixo em inglês. O mesmo valendo em português: em (23) não se afirma que os arquivos ficaram organizados rapidamente na situação anterior (se existiu) à repetição desse estado, denotada pela expressão envolvendo o prefixo.

(23) Pedro reorganizou os arquivos rapidamente.

\section{Outras observações sobre os prefixos}

Uma das ideias defendidas neste trabalho é que os verbos que implicam mudança de estado e aceitam a prefixação des- tipicamente geram particípios que possuem a interpretação de estado alvo de um evento ${ }^{10}$. Um dos testes mencionados para identificar estados alvo envolve o advérbio ainda (KRATZER, 2000). Mas como fica uma segunda anexação do prefixo? O verbo a que ele se anexa, já contendo des-, gera um particípio cuja leitura é de estado alvo?

Tome-se (24) abaixo. O particípio descolorido denota um estado inversível, como o mostra a presença do advérbio ainda na frase.

(24) “Enquanto isso vou testando as cores escuras no que ainda está descolorido. Logo, não se assuste. Solto não aparece e preso ele fica branco". ${ }^{11}$

\footnotetext{
${ }^{9}$ Em Medeiros (2012) apresentei alguns exemplos de intercâmbio posicional entre os prefixos, que encontrei na internet. Todos envolviam verbos que a literatura chama de verbos de criação. Na ocasião, considerei que mostravam que as posições dos prefixos eram intercambiáveis sempre; mas hoje entendo que essa afirmação não pode ser generalizada para todos os predicados. Assim, a questão que agora se coloca é: por que poderiam intercambiar-se (ou por que seria um pouco mais aceitável o intercâmbio?) na classe dos verbos de criação, mas não em outras classes? Não tenho meios de responder a essa pergunta no atual estágio desta pesquisa.

${ }^{10}$ Há, no entanto, contraexemplos. O particípio de aparecer, aparecido, não denota um estado alvo ( ${ }^{*}$ Pedro ainda está aparecido), mas a anexação do prefixo des- é permitida, com idiomatização: Pedro desapareceu e Pedro ainda está desaparecido.

${ }^{11} \mathrm{Ver}<\mathrm{http} / / /$ djulisnicestuff.blogspot.com.br/2012/02/cores-claras-retoque-mechas-e-candy.html〉.
} 
É possível imaginarmos contextos em que um particípio com um segundo prefixo destambém tenha leitura de estado alvo, inversível. Suponha uma situação em que um rapaz está tentando marcar um encontro com uma moça indecisa, que muda de ideia sucessivas vezes. A frase irônica a seguir, do rapaz já impaciente, é certamente incomum, mas, parece-me, aceitável:

(25) Gostaria de saber se nosso encontro ainda está desdesmarcado ou se você mudou novamente de ideia.

A situação é um pouco diferente para o prefixo re-. Particípios passados de verbos que aceitam o prefixo re- podem denotar estados inversíveis. Por exemplo, a sentença (26) mostra que o estado "enterrado" pode ser invertido - portanto, o particípio de enterrar, aqui, denota um estado alvo.

(26) O tesouro ainda está enterrado na praia.

Mas, na frase (27), as coisas são um pouco diferentes.

(27) O tesouro está reenterrado.

Aqui, o particípio denota precipuamente o estado de determinada tarefa ter-se cumprido: ou seja, o particípio denota, na melhor das hipóteses, o estado resultante do evento, no sentido de Parsons (1990), não o estado alvo de reenterrar (ainda que o evento de reenterrar tenha um estado alvo). Note-se que, quando incluem o advérbio ainda, sentenças com o particípio derivado do verbo enterrar prefixado com re- são um tanto degradadas em relação às com particípio do verbo não prefixado:

(28) ??O tesouro ainda está reenterrado.

Ao que parece, enquanto des- toma somente estados alvo, re- é menos restritivo, podendo tomar tanto estados alvo (como em reenterrar as raízes) como estados resultantes de eventos (como em redemonstrar o teorema de Pitágoras).

Outra coisa importante sobre os verbos com os prefixos re-e des-é o fato de que seus argumentos externos são excluídos de qualquer relação com os estados pressupostos. Por exemplo, se o governo desmilitarizou as polícias, o pressuposto é de que as polícias fossem militares antes da sua desmilitarização, mas isso não quer dizer que o (mesmo) governo as militarizara antes de desmilitarizá-las. Ou seja, o argumento externo do verbo não é o agente ou causador necessário do estado (pressuposto) negado pelo prefixo des-. O mesmo vale para o prefixo re-. Veja-se o exemplo (29) abaixo:

(29) Um matemático redemonstrou o teorema.

Pressupõe-se que o teorema já estivesse demonstrado antes de sua redemonstração, mas isso não quer dizer que o mesmo matemático tenha sido o responsável por sua demonstração anterior. 
No exemplo com o prefixo re- acima, a exclusão do agente é incontroversa. Contudo, a questão parece ser um pouco menos clara em casos como o do verbo ler, do verbo interpretar ou do verbo entrar, encontrados na sequência (19) acima. Que estados estariam envolvidos aqui: os estados "lido", "interpretado", "entrado"? Considerarei que se trata, nos casos de ler e interpretar, do estado resultante atingido pelo complemento do verbo: o estado de algo ter sido lido ou interpretado. Mesmo que assim seja, é possível que a releitura não envolva o agente da primeira leitura?

Imaginemos a seguinte situação. Uma ação judicial está em andamento. Após a divulgação da sentença, os advogados da parte prejudicada descobrem que o juiz que julgou a ação era parte interessada, e pedem judicialmente que a ação seja julgada novamente, por outro juiz. O recurso é julgado procedente e um novo juiz então relê os autos do processo e inverte a sentença dada anteriormente.

Aqui, o novo juiz relê os autos sem os ter lido antes - ou seja, poderíamos pensar que, aqui, se repete o estado resultante "lidos" dos autos do processo, para a emissão da nova sentença - mas o segundo leitor não é o mesmo da primeira leitura. Raciocínio semelhante vale para os exemplos com o verbo interpretar: o "Rei Lear" pode ser reinterpretado por outro ator no teatro, sob determinadas circunstâncias.

Com relação a entrar, creio que (i) o verbo seja de fato inacusativo e (ii) haja pelo menos um estado alvo disponível fornecido pelo sintagma preposicional. Como a parte da estrutura que fornece o estado alvo não inclui a raiz do verbo, ele não aceita o prefixo des-, mas aceita o prefixo re-, anexado acima (ver esquema (30) a seguir).

\section{A proposta}

Supondo que o VP é decomponível em até três níveis - o do sintagma raiz (que pode ser uma estrutura de predicação envolvendo um adjetivo e o complemento do verbo, como, talvez, em (des)fertilizar - ver esquema (38)), o do vP e o do Voz-P -, que sintagmas raízes podem veicular estados e as variáveis de evento são introduzidas pelo morfema verbalizador (MARANTZ, 2007), e que o morfema que introduz o evento pode trazer um estado resultante associado, proponho o seguinte esquema para explicar a distribuição dos prefixos analisados aqui: 


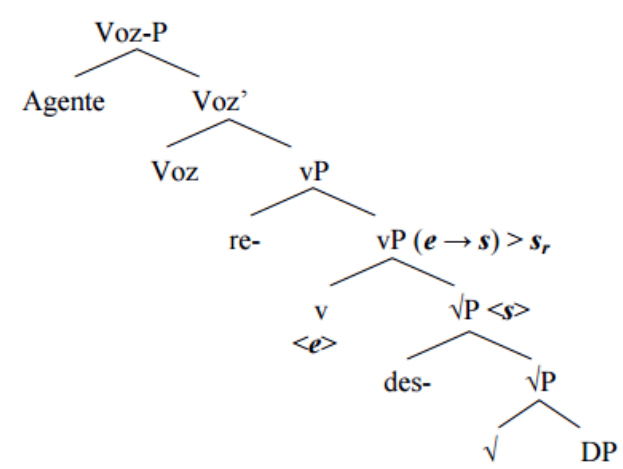

A estrutura acima toma alguns pressupostos importantes. O primeiro, já mencionado na introdução a este artigo, é que os prefixos em questão são modificadores adverbiais, introduzidos na estrutura via pair-merge ou algo que o valha. Mas por que adoto essa posição? Note-se que, como típicos advérbios, os prefixos aqui analisados não mudam a categoria dos constituintes aos quais se anexam. Se os interpretássemos como núcleos categorizadores, uma das consequências seria um aumento no número de entradas no léxico (ou no número de feixes de traços, com a mesma realização fonológica, disponibilizados pela lista 1 ou no número de entradas homófonas na lista 2), para dar conta de sua ocorrência em classes de palavras distintas (nomes não derivados, verbos, adjetivos não derivados etc.), preservando a categoria da base. Se os tomássemos como itens funcionais anexados à estrutura via set-merge, projetariam sua categoria, e uma segunda ocorrência do prefixo não tomaria como base a categoria tomada pela primeira ocorrência. Ademais, a depender de onde se anexa o prefixo, teríamos uma mudança na categoria final da estrutura (deixaria de ser verbo ou nome, por exemplo, e passaria a ter a categoria do nó funcional correspondente), o que pode ser um problema. Assim, a melhor alternativa é tomar os prefixos como advérbios adjungidos às estruturas em que ocorrem. Entretanto, é preciso esclarecer o seguinte: os prefixos, aqui, são funcionais ou semifuncionais (ou seja, não são estruturas que envolvam uma raiz e um núcleo funcional categorizador adverbial); a questão é que são adjungidos às estruturas, não tomam seus alvos como complementos.

O segundo é que, numa componente morfológica ou morfofonológica (assumindo a arquitetura da Morfologia Distribuída), movimentos sucessivos de núcleo dão conta da ordenação dos morfemas (prefixos, raízes e sufixos) na forma final da palavra derivada. Proponho que os movimentos de núcleo, pelo menos na componente morfológica, possam ter como alvo núcleos adjungidos à estrutura sintática. Assim, a primeira coisa que o esquema acima explica é a assimetria posicional entre os dois prefixos: o prefixo des- modifica diretamente o sintagma raiz (ou a camada mais encaixada dentro do sintagma verbal), e, portanto, na sucessão de movimentos de núcleo, é o mais interno na estrutura morfológica da 
palavra; o prefixo re-, como toma o vP, necessariamente ocorre antes do prefixo des- na sequência dos prefixos, sendo, pois, o mais externo. Outras propostas na literatura procuram dar conta da coocorrência dos prefixos aqui estudados numa mesma palavra. Por exemplo, a abordagem lexicalista de Schwindt (2001), dentro do quadro da Fonologia Lexical. Não é claro, entretanto, para mim, como sua análise lida com o fato de a ordenação desre-, quando resignifica repetição, ser anômala, uma vez que os dois prefixos são possíveis ocupantes das duas posições postuladas pelo autor para prefixos.

$\mathrm{O}$ fato de os dois prefixos estarem em posições mais baixas em relação ao núcleo Voz explica, ainda, a exclusão do agente do verbo. Do ponto de vista sintático, o agente fica fora do escopo de qualquer dos dois prefixos (ver STECHOW, 1996 e MARANTZ, 2007, entre outros, para propostas semelhantes, baseadas na ideia de escopo sintático, para o advérbio wieder do alemão e o prefixo $r e$ - do inglês).

Outra propriedade que a estrutura explica é o fato de que o particípio do verbo envolvendo o prefixo $r e$ - tem tipicamente a interpretação de estado resultante, enquanto o particípio do verbo com o prefixo des- pode ter interpretação de estado alvo, inversível. Vou assumir aqui que, translinguisticamente, particípios com interpretação de estado alvo podem ter duas origens estruturais: (1) anexação de um morfema aspectual diretamente a um sintagma raiz, onde a raiz tem leitura de estado (EMBICK, 2004; particípios em -tos, no grego: ALEXIADOU; ANAGNOSTOPOULOU, 2008); (2) anexação de um morfema aspectual acima de um vP cujo verbalizador é um alossema não-eventivo de v, como proposta de Marantz (2013) - talvez o que ocorre no português, pois explicaria a presença da vogal temática em todos os particípios e explicaria facilmente casos como o de (des)mobilizado, por exemplo, que tem um verbalizador realizado por -iz-, mas pode ter leitura de estado alvo (os militantes ainda estão (des)mobilizados). Se des- se anexa abaixo do verbalizador, pode ocorrer numa dessas duas formas participiais, mostradas nos esquemas (31) a seguir. Como o prefixo re- se anexa ao vP eventivo (vemo-lo no esquema (32)), o particípio de um verbo que o contenha terá que levar em conta o evento (KRATZER, 1999). A ideia é que, mesmo que re- esteja envolvido na repetição de um estado alvo, como em reenterrar as raízes, ele, para ser recursivo, precisa devolver um evento no cálculo semântico (ver seção 4.1), sobre o qual se formará o particípio. Se entendemos que particípios gerados acima de núcleos que introduzem eventos são formas com leitura de estado resultante, explicamos por que a expressão o tesouro está reenterrado, em (27), tem as propriedades que tem. 

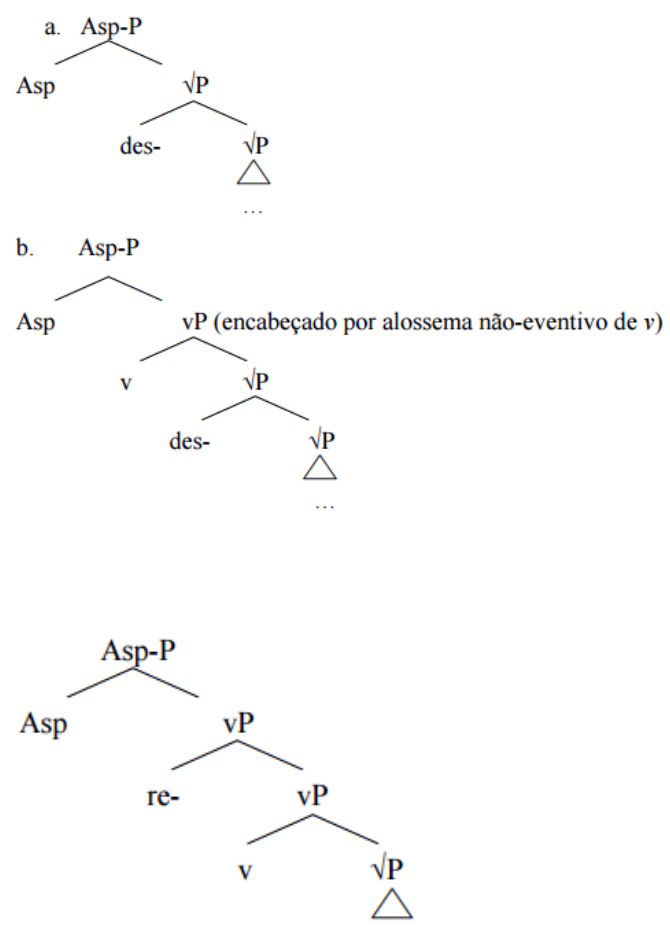

A estrutura também dá conta da relação entre a quantificação do complemento e o operador introduzido pelo prefixo. Assumindo que os complementos devem mover-se para fora do vP (ou do Voz-P) na sintaxe, visível ou encoberta (checagem de Caso: CHOMSKY, 1995), explicamos por que sempre a quantificação do complemento tem escopo sobre o operador introduzido pelo prefixo, seja re- ou des- (MEDEIROS, 2012; ALEXIADOU et alii, 2014). Veja-se a representação (34) a seguir, para a sentença em (33).

(33) João desmontou todas as máquinas.

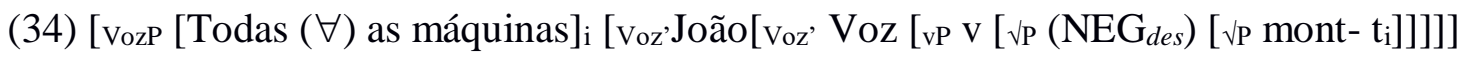

Aqui, como se vê, o operador universal do complemento terá escopo sobre o operador de negação introduzido pelo prefixo. Raciocínio semelhante vale para a relação entre quantificadores no complemento do verbo e o operador introduzido pelo prefixo re-.

A estrutura também explica por que des- ocorre em nomes e adjetivos não derivados de verbo, mas re- ocorre tipicamente em nomes e adjetivos deverbais, quando ocorre em nomes e adjetivos (OLIVEIRA, 2004). Como des- não seleciona uma categoria, faz somente seleção semântica (MEDEIROS, 2010), a categorização pode ser qualquer uma, desde que veicule um tipo semântico compatível. Já re- toma um vP, e só ocorrerá em nomes e adjetivos que sejam derivados de um verbo, portanto.

Por fim, a proposta explica por que as modificações adverbiais ficam fora do escopo dos prefixos: elas tomam camadas mais altas, acima do núcleo Voz. Ou seja, se João remontou as 
máquinas rapidamente, o sintagma verbal prefixado (e mais seu núcleo Voz e o agente) está sob o escopo do modificador adverbial "rapidamente", o que explica a única interpretação possível (ver WILLIAMS, 2007 e MARANTZ, 2007 para propostas semelhantes em relação ao prefixo $r e$ - do inglês).

\section{Uma nota sobre abordagens para morfemas repetitivos em outras línguas}

Nesta seção, falarei rapidamente de análises do prefixo re- (e de outros itens repetitivos) para outras línguas - e procurarei deixar claro o porquê de não as adotar aqui.

Keyser e Roeper (1992) defendem que o prefixo re- no inglês ocupa uma posição abstrata de clítico, obrigatória na estrutura do sintagma verbal ${ }^{12}$. Há então uma operação de composição que move o prefixo e faz com que ele forme um composto com o verbo. A posição de clítico pode ser ocupada por núcleos ou constituintes mais complexos encabeçados por qualquer uma das classes maiores; também pode ser ocupada por adjuntos, como é o caso do prefixo re-. A proposta explica restrições de coocorrência, como a impossibilidade de haver recom clíticos dativos, re- com argumentos indiretos (em verbos bitransitivos), com partículas, entre outros: re- não co-ocorrerá com esses elementos em inglês porque eles já ocupam a posição em que o prefixo seria anexado na estrutura do sintagma verbal, a posição de clítico. Vale esclarecer que a postulação de um "gabarito" verbal com uma (única) posição de clítico obrigatória, eventualmente ocupada pelo prefixo, não elimina a possibilidade de recursividade do prefixo: um mecanismo de apagamento do vestígio deixado por adjuntos movidos permite que a posição original do prefixo (a posição de clítico), após a composição, fique disponível para nova inserção do prefixo.

Há, contudo, duas dificuldades nessa proposta para os dados do português. A primeira é que, até onde posso ver, a posição de clítico poderia ser ocupada também pelo prefixo des-, e, com o mecanismo de apagamento dos vestígios de adjuntos, poderíamos gerar qualquer ordem entre re- e des-, o que não é permitido. O segundo problema é que a proposta assume que o argumento indireto de verbos bitransitivos ocupa a posição de clítico, o que explica sua não coocorrência com o prefixo em inglês. A questão é que o prefixo ocorre em muitos verbos bitransitivos do português (repor o vaso na mesa da sala, por exemplo), e, portanto, seria preciso ou supor que re- não ocupa a posição de clítico postulada (o que anularia qualquer possibilidade de transposição da proposta para o português) ou que a estrutura de pelo menos

${ }^{12}$ A proposta é que a existência dessa posição de clítico no sintagma verbal seja um universal, não uma exclusividade do inglês, ainda que os autores só tratem dos dados em inglês. 
alguns verbos bitransitivos do português é diferente da estrutura proposta para o inglês. Notese, ademais, que em português não há problema na coocorrência de clítico dativo com o prefixo: o patrão me recolocou na antiga função. Há, além disso, críticas em relação aos dados feitas por Marantz (2007) que me parecem pôr em dúvida a base empírica sobre a qual a proposta se assenta.

Stechow (1996) propõe uma decomposição sintática do sintagma verbal nos moldes da semântica gerativa, com o advérbio wieder ("novamente") podendo ocupar mais de uma posição na estrutura proposta. Assim, wieder acima do núcleo Voz tem leitura repetitiva (que inclui o agente da ação) e wieder dentro da estrutura do sintagma verbal, tomando uma estrutura estativa interna, tem a chamada leitura restitutiva (repete um estado resultante, não um evento incluindo seu agente).

Contudo, a análise é para um advérbio, que ocorre nas sentenças do alemão em posições diversas, o que não é o caso do prefixo re- do português. Ademais, seu escopo de leitura restitutiva toma diretamente um sintagma que denota um estado do complemento, o que equivaleria ao nível do sintagma raiz no esquema apresentado em $(30)^{13}$. Assim, a não ser que façamos algum tipo de estipulação de ordem, teríamos alguma dificuldade em dar uma explicação para o fato de $r e$ - ter sempre escopo sobre des-, mas nunca o inverso, pois os dois prefixos seriam modificadores do mesmo constituinte sintático (do mesmo nível no sintagma verbal).

Cardinaletti (2003) propõe que o prefixo de repetição ri- no italiano seja um adjunto (um item lexical, não funcional) incorporado ao verbo. Seguindo Cinque, Cardinaletti (2003) assume que existem duas posições na estrutura sintática para a colocação de advérbios de repetição, e essas duas posições podem ser ocupadas pelo prefixo. $\mathrm{O}$ conjunto de propostas explica os seguintes fatos sobre o italiano: (i) o prefixo pode ser incorporado ao auxiliar em formas compostas com o verbo avere; (ii) nos verbos somente duas ocorrências do prefixo são permitidas. No português, contudo, o prefixo não pode se anexar ao auxiliar, somente ao verbo principal, e também é possível encontrarmos construções enfáticas com mais de duas ocorrências do prefixo.

Marantz (2007) assume que o prefixo toma diretamente o complemento do verbo. O complemento, que tipicamente denota uma entidade, sofre uma mudança de tipo semântico no

\footnotetext{
${ }^{13}$ Stechow (1996) decompõe o sintagma verbal em VozP-VP-XP, onde o XP é um sintagma que denota um estado resultante do evento e é o mais encaixado na estrutura do sintagma verbal. Na leitura restitutiva de wieder, o advérbio toma o sintagma XP. Na proposta, o núcleo X não é a raiz do verbo. De algum modo (ou por alguma transformação no estilo da semântica gerativa), $\mathrm{X}+\mathrm{V}+\mathrm{Voz}$ é convertido no verbo que encabeça o sintagma verbal.
} 
contexto de alguns verbos e passa a denotar uma espécie de evento de mudança de estado da entidade denotada por ele. O prefixo só é licenciado quando o complemento é interpretado como evento que tenha um estado resultante. Ou seja, o prefixo seleciona categorialmente um DP, mas semanticamente um evento/estado.

A proposta explica fatos da língua inglesa, mas não há clareza sobre alguns de seus pontos. Por exemplo, o mecanismo de mudança de tipo semântico do complemento não é formalizado e seu alcance tampouco é definido. Mas o principal problema é que, para Marantz, o fato de re-ser um modificador de um complemento direto interpretado como evento de mudança de estado explica o porquê de o inglês não aceitar que o prefixo seja licenciado em verbos bitransitivos: tais verbos envolvem uma small-clause que relaciona os dois complementos do verbo, onde o objeto direto não é tipicamente interpretado como um evento de mudança de estado. Se adotássemos a mesma lógica para o português, o prefixo re- não poderia ser licenciado em verbos bitransitivos, mas, obviamente, esse não é o caso.

Em francês, o prefixo re-pode ocorrer até mesmo como forma livre, segundo Sportiche (2012). A abordagem do autor é uma versão de Stechow (1996) combinada com elementos da proposta de Cardinaletti (2003), mostrando diferenças de escopo na interpretação do prefixo a depender do lugar em que ocorre. O prefixo re- em português não tem o mesmo comportamento, e não pode ser tratado do mesmo modo.

Alexiadou et alii (2014) propõem que o prefixo re- no inglês é um núcleo categorizador v. Com essa proposta, não é claro como ele poderia ser recursivo no português (ou no inglês): se sua função é, entre outras, categorizar a raiz do verbo, qualquer outra anexação de re- seria uma espécie de recategorização vácua, a não ser que o léxico disponibilize mais de um prefixo re-, praticamente com as mesmas propriedades semânticas do re-categorizador, para os casos de segunda ocorrência do prefixo. Além disso, a definição semântica dada pelos autores para esse categorizador não é recursiva, o que nos levaria de novo à indesejável existência de um segundo re-, só disponível para as situações em que temos repetição do prefixo na palavra. Outros itens repetitivos, de outras línguas, comentados no trabalho de Alexiadou e colegas, têm menos interesse para os fenômenos que estamos descrevendo aqui e, de modo geral, os autores adotam alguma versão da proposta de Stechow (1996) para lidar com eles.

Em vista das dificuldades apontadas nos parágrafos anteriores, não é possível fazer uma mera transposição de alguma dessas abordagens para o português. Isso não quer dizer, contudo, que os trabalhos de que trato nesta seção não contribuíram para a proposta apresentada em (30). 


\section{Eventos e estados}

Tomemos novamente a estrutura (30). Como vimos acima, a proposta é que a camada mais interna, que corresponde ao sintagma raiz, possa veicular um estado. A camada imediatamente mais alta, encabeçada por $v$, estabelece o nível do evento (eventualidade dinâmica). Suponhamos, ainda, que determinados verbalizadores selecionem estados e estabeleçam uma relação de implicação entre as eventualidades envolvidas na estrutura (HALE; KEYSER, 2002).

O prefixo des- seleciona um estado (como o verbalizador acima dele) e devolve um estado. O morfema $v$ introduz um evento que acarreta o estado veiculado pela estrutura ccomandada por ele e introduz também um estado resultante (PARSONS, 1990), $\boldsymbol{s}_{\boldsymbol{r}}$, que acompanha a culminação do evento, conforme representação em (30). O estado resultante é um estado do complemento do verbo. Uso o símbolo ">" para distinguir a relação entre $\boldsymbol{e}$ e $\boldsymbol{s}$ (de implicação ou causação) da relação que existe entre o evento inteiro e seu estado resultante, $\boldsymbol{s}_{\boldsymbol{r}}$, que é de outra natureza.

Aqui, adoto proposta de Medeiros (2010), em que o prefixo des- tem a seguinte definição recursiva: [[NEG] $]_{d e s}:=\lambda \mathrm{f}_{<\mathrm{s}, \mathrm{t}} . \lambda \mathrm{s}^{\prime} \cdot[\sim \mathrm{f}(\mathrm{s})]$. Ou seja, o prefixo toma um estado $s$ e devolve o estado não-s. As propriedades de seleção semântica do prefixo forçam uma leitura em que o sintagma raiz em (30) tenha a seguinte denotação: $\lambda s . R(s,[[D P]])$, onde [[DP]] é a denotação do DP complemento do verbo (uma entidade), $s$ é uma variável (davidsoniana) de estado e $\mathrm{R}$ traz o conteúdo lexical da raiz. A ideia que defendo neste ponto do texto é que a raiz não introduza, por si mesma, uma variável de estado, mas o sintagma raiz, em Forma Lógica, passe a denotar uma função que relaciona estados a valores de verdade por conta das propriedades selecionais do prefixo (ou do verbalizador acima dele, caso não haja o prefixo). Como um estado é sempre um estado de algo, o significado estrutural envolve um DP sobre o qual $\mathrm{R}$ predica, e somente um sintagma raiz com um complemento será compatível com o prefixo (ou com um verbalizador de determinado tipo). Adotando o referencial teórico da Morfologia Distribuída, podemos pensar que, em Forma Lógica, o sintagma raiz recebe a denotação (digamos, puramente estrutural) acima, $\lambda \mathrm{s} . \mathrm{R}(\mathrm{s},[[\mathrm{DP}]])$, por conta das propriedades de seleção do prefixo ou do verbalizador; na interface conceitual, a lista 3 (Enciclopédia) fornece o conteúdo de R. A depender do tipo de significado encontrado na lista 3, uma raiz pode ser mais ou menos compatível com a semântica estativa veiculada pela expressão formal apresentada. Importante salientar que, nessa visão, a raiz não faz seleção semântica ou categorial, nem atribui papéis temáticos aos complementos dos verbos. Isso explica os 
julgamentos de gramaticalidade associados aos prefixos, que não são categóricos. Com efeito, os significados lexicais podem ser mais ou menos compatíveis com o significado estrutural determinado pelos itens funcionais envolvidos - mas o fato de um conteúdo enciclopédico ser não muito compatível com o significado estrutural $\lambda \mathrm{s}$.R(s, [[DP]]) não torna a expressão realmente agramatical. Assim, é possível atribuir uma leitura não convencional a sentenças como "o ator desinterpretou o rei Lear no Teatro" porque os significados enciclopédicos são “maleáveis", enquanto os significados estruturais não o são ${ }^{14}$.

Para que fiquem mais claras as propostas acima, tomemos o exemplo do predicado destampar o ralo. O sintagma raiz é um constituinte que contém a raiz de tampar e o complemento (DP) do verbo: o ralo. O prefixo de negação des- combina-se ao sintagma raiz e estabelece que este sintagma denotará um estado do ralo (a expressão formal $\lambda \mathrm{s}$.R(s, [[DP]])) e o negará ( f(s)). Além disso, introduzirá a pressuposição de que o ralo está em tal estado ao iniciar-se o evento denotado pelo predicado. A natureza desse estado é determinada pelo conteúdo enciclopédico da raiz: algo como o estado de ter uma cobertura, capa ou tampa. $\mathrm{O}$ verbalizador acima do sintagma raiz modificado pelo prefixo introduzirá o evento que acarreta o estado atingido pelo complemento: o estado "não-tampado".

O prefixo des- nega o estado denotado pelo sintagma raiz - e introduz uma pressuposição. Proporei (contra MEDEIROS, 2012) ${ }^{15}$ que o prefixo re-, que toma o vP, repete ou o estado alvo, quando este estado é expresso por alguma parte da estrutura do VP (por exemplo, o estado "enterrado" no predicado reenterrar as raízes da árvore), ou o estado resultante decorrente do evento, $s_{r}$, e devolve um evento com um estado resultante (por exemplo, no predicado reutilizar os copos descartáveis, algo como o estado de os copos terem sido reutilizados). Ambas as eventualidades estão disponíveis para o operador albergado pelo prefixo na estrutura (30) acima. O esquema abaixo representa a ideia:

\footnotetext{
${ }^{14}$ Para uma discussão interessante sobre esse ponto, ver Borer (2005).

${ }^{15}$ Meirelles e Cançado (2014) já apontavam problemas importantes em Medeiros (2012). Além disso, sugerem que não só fatores semânticos estejam em jogo no não licenciamento do prefixo.
} 


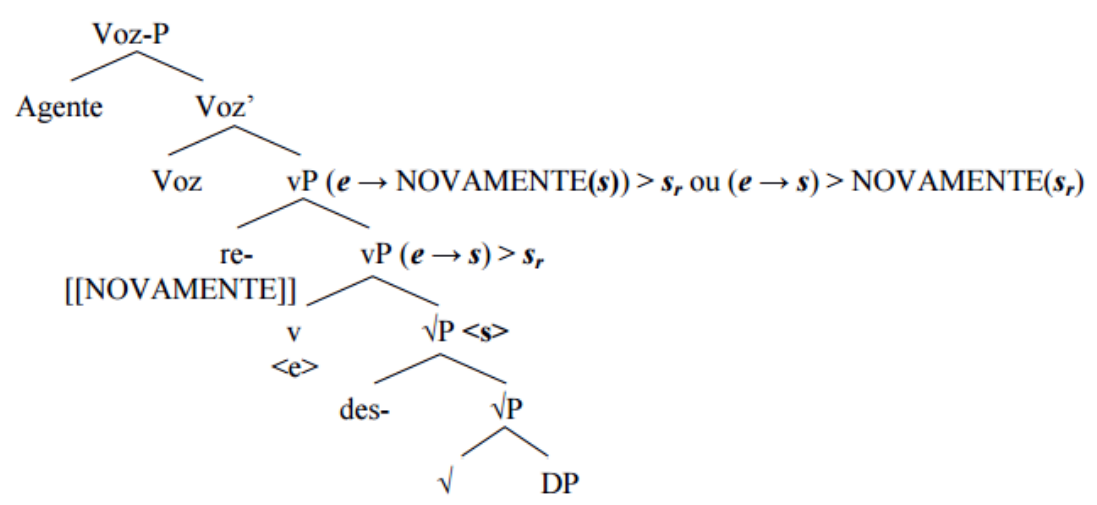

Como acontece com alguns advérbios, o operador introduzido por re-pode atuar sobre uma ou outra eventualidade dentro da estrutura por ele modificada, quando duas estão disponíveis no seu escopo. O prefixo então toma uma função que relaciona eventos a valores de verdade (veiculada pelo vP) e devolve eventos - com estados resultantes. O operador de repetição toma ou o estado (alvo) que decorre do evento ou seu estado resultante. A ideia é que, no nível do vP, os dois estados estejam disponíveis para a modificação - ou seja, nesse ponto da derivação, há como que um "achatamento" da estrutura, que torna os dois estados equidistantes de $\mathrm{re}^{-1}{ }^{16}$. É evidente que, com isso, se introduz um pressuposto: ou o estado alvo do evento tem que ter sido um estado do complemento do verbo em algum momento anterior ao tempo do evento veiculado pelo verbo ou o evento completo, culminado, tem que ter tido uma ocorrência anterior, para o mesmo referente do complemento do verbo.

Resta ainda um ponto importante a respeito da relação entre o prefixo $r e$ - e a questão da recursividade. Note-se que após a primeira anexação do prefixo re-, os estados alvo e resultante, disponíveis na camada vP, não estão mais disponíveis para uma segunda anexação do prefixo. Se alguém diz que um poderoso deus do Olimpo rerrecurvou a Terra, leva-se em conta o fato de a Terra já ter sido recurvada alguma vez, não o fato de ela ter sido simplesmente curvada ou o fato de algum dia ela ter sido curva. A ideia que gostaria de esboçar aqui para explicar essa propriedade é a seguinte: o operador de repetição toma qualquer um dos dois tipos de estado, desde que estejam disponíveis; na camada vP eles estão disponíveis para o operador; entretanto, quando o prefixo entra na estrutura, fecha-se o acesso desses dois estados a alguma camada mais alta, disponibilizando-se somente um estado resultante, que seria um subproduto da anexação do prefixo. Ou seja, na primeira anexação do prefixo: $(\mathrm{e} \rightarrow \operatorname{NOVAMENTE~}(\mathrm{s}))>\mathrm{s}_{\mathrm{r}}$ ou $(\mathrm{e} \rightarrow \mathrm{s})>\operatorname{NOVAMENTE}\left(\mathrm{s}_{\mathrm{r}}\right)$; na anexação do segundo prefixo: e' > NOVAMENTE $\left(\mathrm{s}_{\mathrm{f}}\right)$, onde $e$ ' é o evento introduzido pela primeira ocorrência do prefixo e $s_{f}{ }_{f}$ é o estado resultante

\footnotetext{
${ }^{16}$ Essa equidistância não vale para um estado alvo abaixo do prefixo des-.
} 
associado a esta ocorrência; numa possível terceira anexação dos prefixos: e" > NOVAMENTE (s", f); e assim por diante ${ }^{17}$.

Como o prefixo também ocorre em predicados cujos verbos não derivam de nada que forneça um estado alvo ou não estão associados a um particípio com leitura de estado alvo, (35) acima não representa a única estrutura possível para o licenciamento de $r e$-. Tomem-se as sentenças (36) abaixo:

(36) a. Pedro reutilizou os copos descartáveis.

b. O matemático redemonstrou o teorema.

Em (36) o prefixo repete somente um estado resultante, não um estado alvo (que, de fato, não está disponível). Aqui, o sintagma raiz não fornecerá, tipicamente, um estado para ser modificado pelo prefixo des-. Assumindo, neste artigo, que verbos como demonstrar envolvam uma estrutura em que a raiz é modificadora de $\mathrm{v}$ e o complemento não é diretamente concatenado a ela, temos a seguinte estrutura (inspirada em MARANTZ, 2007, entre outros).

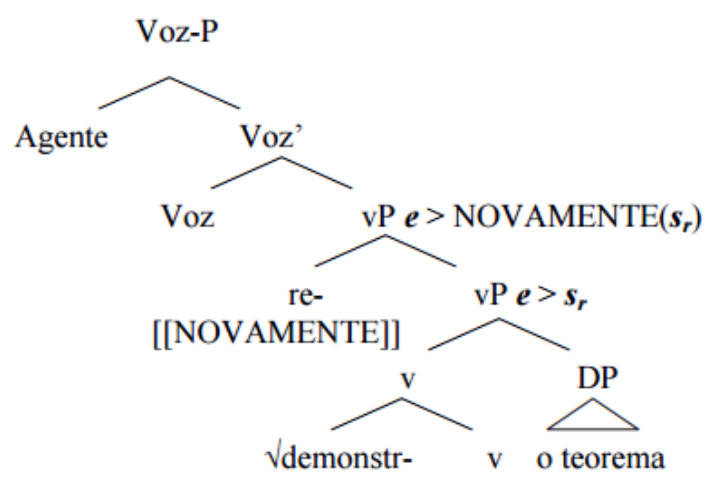

Para completar a seção, vale mencionar o caso dos verbos derivados de adjetivos, como fertilizar ou igualar. Aqui, o adjetivo fornece uma variável de estado, que alimenta o prefixo des- ou o verbalizador, caso não haja prefixo. A camada mais baixa fornece, portanto, um constituinte cuja denotação já é compatível com a seleção do prefixo (ou do verbalizador). A estrutura abaixo para o verbo "fertilizar" apresenta a ideia.

\footnotetext{
${ }^{17}$ A dificuldade aqui talvez seja explicar como o objeto direto, muito encaixado na estrutura, está disponível para um $\mathrm{s}_{\mathrm{f}}^{\mathrm{i}}$ qualquer introduzido por uma ocorrência de $r e$ - acima da primeira. Isso fica para trabalho futuro.
} 


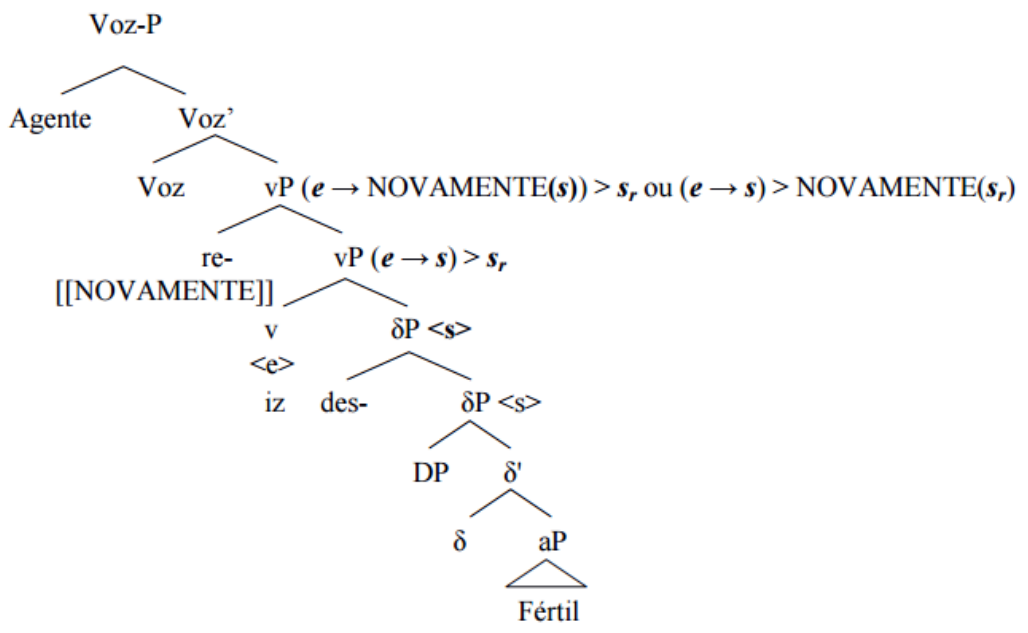

Aqui, o adjetivo move-se para $\delta$ (projeção estendida do adjetivo ou relacionador, proposta inspirada em HALE; KEYSER, 2002 e DEN DIKKEN, 2005) ${ }^{18}$ e o complexo formado move-se para des- e assim por diante. Os particípios seriam formados sobre vP e, por isso, tipicamente denotam somente estados resultantes.

\section{Sobre fases e os prefixos re- e des-}

As teorias de fases em palavras têm considerado que morfemas categorizadores são os responsáveis por definir domínios cíclicos ou fases (MARANTZ, 2001; MARANTZ, 2013; EMBICK, 2010, entre outros), onde se estabelecem significados e pronúncias especiais para raízes (a primeira fase ou ciclo). Ou seja, para trabalhos como Marantz (2001), Arad (2005), Marvin (2002), entre outros, quando um morfema categorizador é combinado a uma raiz diretamente, a estrutura (ou a raiz) sofre a operação de transferência para as interfaces (CHOMSKY, 2001), e seus significado e pronúncia são estabelecidos. A condição de impenetrabilidade de fase (sigla PIC: CHOMSKY, 2001) garante que significado e pronúncia da estrutura enviada não mais serão alterados, independentemente de como se desenvolva a derivação após a transferência.

A questão é que se as fases são determinadas por morfemas categorizadores, mas não por adjuntos - pois estes não definem categoria e, para trabalhos como Lebeaux (1988), Chomsky (2001) etc., são, de fato, contra-cíclicos, anexados à estrutura após as operações de movimento - e se os prefixos aqui analisados são adverbiais, como defendi ao longo deste

\footnotetext{
${ }^{18}$ Os autores mencionados, no entanto, defendem que a estrutura encabeçada por $\delta$ seria a de uma típica smallclause, não parte de um sintagma verbal, como proponho aqui.
} 
artigo, parece-me que nada impediria que tivéssemos mais de um prefixo recursivo dentro de uma fase, tendo possível influência sobre a determinação de significado especial da raiz.

Isso valeria para qualquer tipo de estrutura, analisada ou não neste artigo, mas, aqui, o problema é evidente no caso do prefixo des-, considerando as propostas defendidas nas páginas anteriores. Se ele de fato é recursivo, e considerando a estrutura proposta em (30), uma segunda ocorrência do prefixo des- se anexaria ao sintagma raiz já prefixado, abaixo do morfema verbalizador, que, segundo as teorias disponíveis na literatura, definiria uma fase. Veja-se o esquema abaixo:

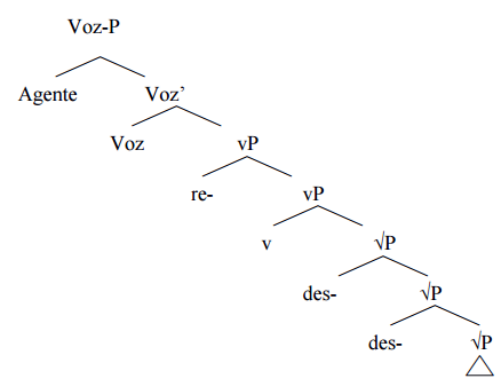

(Note-se que a ordem redesdes- é possível (o governo redesdesmilitarizou a polícia), mas não outras ordens envolvendo os dois prefixos, o que favorece a proposta apresentada em (39) acima).

Mas um contexto com uma ocorrência do prefixo é diferente de um contexto com duas ocorrências do prefixo; então, por que um segundo prefixo (ou um terceiro, um quarto etc.) não dispararia um novo significado para a raiz, considerando que a fase só se fecha acima da segunda (ou terceira ou quarta) anexação do prefixo em (39)? Significados novos por conta de segundas ou terceiras ocorrências dos prefixos recursivos parecem não existir, contudo: pode até haver um significado especial para uma raiz ligado à primeira ocorrência de um prefixo recursivo, mas uma segunda anexação do mesmo prefixo não dispara nova negociação de significado $^{19}$. Por exemplo, tomemos (40) a seguir:

(40) As revelações feitas pelo promotor desnortearam o advogado de defesa.

Aqui, o verbo desnortear denota um estado psicológico que foi provocado pelo promotor no advogado de defesa. O verbo nortear, sem o prefixo, não denota necessariamente um estado psicológico, e pode ser usado com objetos diretos não humanos sem atribuir-lhes metaforicamente um estado mental humano (por exemplo: as bússolas serviam para nortear as

\footnotetext{
${ }^{19} \mathrm{O}$ mesmo parece valer para sufixos aumentativos e diminutivos, que também são recursivos. Veja-se que em camisinha temos significado especial para a raiz, mas um segundo diminutivo não dispara renegociação de significado: camisinhazinha refere-se a uma camisinha (preservativo) pequena.
} 
viagens marítimas no século XVI). É possível que outros eventos no julgamento desdesnorteiem o advogado de defesa, mas a segunda ocorrência do prefixo não produz uma renegociação do significado da raiz, já definido em sua primeira ocorrência.

Até onde posso ver, haveria, dentro do modelo teórico adotado neste artigo, duas possibilidades de tratamento para o problema, que, contudo, não são destituídas de dificuldades.

Uma delas seria supor que há alguma condição sobre as entradas na Enciclopédia, estabelecendo que o ambiente sintático para a definição de significado especial de raiz não possa incluir mais de uma adjunção ao mesmo nível. Assim, mesmo que haja mais de um prefixo com potencial para definir significado especial para uma raiz dentro de uma fase, não haveria entrada correspondente na Enciclopédia, pois isso violaria alguma condição sobre essas entradas.

Note-se que é razoável supor que haja uma limitação qualquer para a atribuição de significados especiais em ambientes envolvendo itens recursivos: virtualmente infinitas anexações desses itens são possíveis, e não poderia haver uma entrada enciclopédica distinta definida para cada anexação nessas circunstâncias. Entretanto, a proposta encerra, para mim, duas dificuldades. Em primeiro lugar, não saberia explicar por que somente uma ocorrência de um item recursivo pode definir significado especial. Por que, em alguns casos, não seria permitido que duas ocorrências o fizessem, ou mais de duas? Ou seja, por que haveria uma condição tão restritiva sobre as entradas na Enciclopédia, e por que ela seria tão uniforme? Além disso, a proposta parece duplicar consequências de uma teoria baseada em fases: ou seja, se assumirmos uma teoria de fases para tratar da derivação de "palavras", teremos duas razões para não haver renegociações de significados especiais de raízes: a primeira por conta de alguma versão de PIC (condição de impenetrabilidade de fase - CHOMSKY, 2001); a segunda, por conta de uma restrição sobre as entradas da lista 3.

Outra possibilidade seria a seguinte. Suponhamos que o que estabelece o domínio para negociação do significado especial sejam não exclusivamente os morfemas categorizadores, mas também adjuntos. Defendo, acima, que os prefixos recursivos estudados aqui são adjunções a partes da estrutura do sintagma verbal. Assim, a primeira anexação de um dos prefixos analisados neste trabalho, quando diretamente a um sintagma raiz, definiria um domínio de significado especial. Portanto, segundo a proposta aqui desenhada, o prefixo des-, como os morfemas categorizadores, fecha um ciclo quando é anexado à estrutura, e o sintagma raiz é interpretado como uma função que relaciona um estado (de uma entidade que é seu complemento) com um valor de verdade. A Enciclopédia é consultada e o conteúdo lexical da 
raiz é definido. Outra anexação do prefixo terá que levar em conta o significado já atribuído à raiz.

No que diz respeito ao prefixo $r e-$, as coisas são aparentemente diferentes. A definição de significado especial da raiz já acontece no nível do $v \mathrm{P}$, segundo as propostas encontradas na literatura (adotadas aqui), e, portanto, re- com significado de repetição não cria domínio para leitura idiomática de raiz. Contudo, se levarmos em conta a possibilidade de que um significado estrutural seja "forçado" sobre um sintagma raiz (ou mesmo sobre um vP encabeçado por alossema semanticamente nulo de v), e a possibilidade de o prefixo apresentar alossemia, temos uma situação semelhante à discutida acima. Veja-se o caso do verbo na sentença a seguir:

(41) $\mathrm{O}$ artista realçou os detalhes de sua obra.

Aqui, teríamos uma situação em que o prefixo se adjunge diretamente a um sintagma raiz e força uma interpretação estrutural do tipo $\lambda \mathrm{s} . \mathrm{R}(\mathrm{s}$, [[DP]]), onde $\mathrm{R}$ recebe um dos significados da raiz de "alçar" no contexto do prefixo. Segundo a proposta que estou descrevendo, há uma fase no ponto de anexação do prefixo. Note-se que, nessa análise, o significado do prefixo (qualquer que seja) não é o de repetição e só é definido num contexto de acesso direto à raiz. Tratar-se-ia, pois, de alossema de re-. Como o resultado é um sintagma raiz com uma variável de estado disponível, a anexação do prefixo des- é licenciada ${ }^{20}$. O verbalizador se anexa acima do sintagma raiz, criando um verbo transitivo com estados resultante e alvo disponíveis, além de uma variável de evento. Assim, é possível anexar outro re- sobre a estrutura, recursivo, com significado de repetição (o artista rerrealçou os mais belos detalhes de sua obra).

A proposta, contudo, tem um sério problema: adjunções são, segundo uma parte importante da literatura, contra-cíclicas, e para isso há bastante evidência (ver, por exemplo, FOX, 2002). Então, como um adjunto poderia definir um domínio cíclico?

Não tenho resposta para essa questão. Mas gostaria de dizer que a relação entre adjunção e definição de significados especiais (não composicionais) apresenta evidência empírica interessante, além do ambiente aqui analisado. Sabemos que pode haver expressões idiomáticas verbais envolvendo uma adjunção, como, por exemplo, dormir no ponto, sentar na glória, beber da fonte, cair de quatro, andar nas nuvens, bater com as dez, carregar nas tintas, chutar alto, levantar com o pé esquerdo, viajar na maionese etc. Mas não sei de expressão em que a idiomatização ocorra somente quando mais de um constituinte é adjungido à mesma camada

20 "não quero tão escuro ok? se não vai desrealçar a beleza da Elle - qq" - encontrado em $<$ http://z13.invisionfree.com/innocence_graphics/index.php?showtopic=24\&st=15>. Encontrei várias ocorrências de "desrealçar" na internet. 
sintática - no caso do tipo de exemplo listado, uma expressão idiomática em que seu significado especial (ou outro significado especial) ocorre somente quando um segundo (ou terceiro, ou quarto) adjunto ao sintagma verbal entra em cena.

O paralelo mostra não só que faz sentido pensar que tais prefixos são integrados às estruturas em que ocorrem através de algum tipo de adjunção, como também que, de alguma forma, adjunções podem definir domínios sintáticos de atribuição de significados especiais. Além disso, diria que o paralelo favorece uma abordagem sintática para a estrutura morfológica de verbos prefixados.

\section{Considerações finais e questões abertas}

O artigo oferece explicações para muitas das propriedades dos prefixos apresentadas na segunda e na terceira seções. Em particular, oferece argumentos para uma abordagem baseada em uma decomposição sintática do sintagma verbal - representando uma estrutura de eventos - e nas relações de escopo estabelecidas pelos operadores introduzidos pelos prefixos na estrutura de eventos sintaticamente representada. Por fim, discute a relação entre prefixos recursivos e os domínios de definição de significados especiais para raízes.

Há questões, contudo, que precisam ser consideradas e resolvidas em trabalhos futuros. Algumas já foram mencionadas ao longo do texto; abaixo, apresento outras.

A primeira diz respeito ao fato de que argumentos indiretos de (pelo menos alguns) verbos bitransitivos estão fora do escopo do prefixo $\mathrm{re}^{-{ }^{21}}$. Imagine-se o seguinte cenário: Maria enviou uma carta para uma tia de outro estado, com quem ela não tinha contato havia muitos anos. Alguns dias depois, a carta retornou a Maria, porque os correios não encontraram o destinatário. Maria então resolveu reenviar a carta para uma prima sua, cujo endereço ela sabia estar atualizado, pedindo para que repassasse a carta para a sua tia. No exemplo, o reenvio se dá para um destinatário diferente, e o uso do prefixo é perfeitamente aceitável, de acordo com o meu julgamento ${ }^{22}$.

Note-se que algo semelhante ocorria para os argumentos externos: um matemático pode redemonstrar um teorema que fora demonstrado por um matemático diferente. Essa propriedade era explicada assumindo-se que o prefixo entrava abaixo do núcleo introdutor do argumento externo, o que fazia com que este ficasse fora do escopo do prefixo. Tal estratégia, contudo,

\footnotetext{
${ }^{21}$ Agradeço a Filipe Kobayashi por me chamar a atenção para esse fato.

${ }^{22}$ Entretanto, algumas pessoas informalmente consultadas discordaram do meu julgamento, considerando que o cenário não favorece a ocorrência do prefixo.
} 
não pode ser trivialmente usada com os argumentos indiretos dos verbos bitransitivos. A literatura apresenta inúmeras razões para que o objeto indireto de um verbo bitransitivo ocupe uma posição dentro do sintagma verbal, mais encaixada até do que a do objeto direto. Assumindo que isso seja verdade, teríamos dificuldades com o esquema (30).

Contudo, parece-me que a classe dos chamados verbos bitransitivos não exibe de modo homogêneo essa propriedade. Tomemos o seguinte cenário com o verbo colocar. Pedro comprou um belo vaso de flores para presentear sua esposa. Ao chegar a sua casa, colocou-o na mesa da sala. Sua mulher, contudo, não gostou daquele arranjo e recolocou o vaso em cima da cristaleira. Aqui, o contexto desfavorece o uso do prefixo, de acordo com o meu julgamento. Uma hipótese que poderíamos aventar é que o ponto de anexação do argumento indireto nos sintagmas verbais encabeçados por verbos como enviar é diferente (fora do escopo do prefixo) do ponto em que o objeto indireto é anexado em sintagmas verbais encabeçados por verbos como colocar ou pôr (dentro do escopo). A discussão, no entanto, é complexa e requer investigação aprofundada dessa classe de verbos, o que fica fora do escopo deste trabalho.

A segunda questão está relacionada à não-recursividade do prefixo des- em nomes e adjetivos. Por que não temos coisas como desdesleal ou desdestemor se afirmei o tempo todo que des- é um prefixo recursivo? Creio que a razão esteja, aqui, fora da gramática ou da semântica: como não há evento envolvido, desleal não significa "tornar algo não leal", mas quer dizer simplesmente "não leal". Ora, desdesleal, portanto, seria simplesmente "não não leal", ou seja, "leal". Duas ocorrências do prefixo des- não acrescentam nada que o adjetivo não prefixado já não tenha. Assim, deve ser descartado, pois introduz dificuldades no cálculo semântico que não precisam existir. O problema que permanece é o da pressuposição do prefixo, mencionada na segunda seção deste artigo: o prefixo introduz a pressuposição de um estado do complemento num ambiente verbal encabeçado por um verbo cujo particípio passado (na proposta, a raiz do verbo) denota um estado alvo, não nos outros ambientes em que é licenciado. Note-se que Pedro pode ser desleal sem ter sido leal alguma vez na vida. A questão da pressuposição associada ao prefixo des- é uma questão interessante, e pode ser um efeito colateral de sua ocorrência em determinado tipo de ambiente verbal. Uma discussão mais aprofundada desse tema fica, contudo, para trabalhos futuros.

O terceiro ponto, relacionado ao anterior, é o seguinte: há casos em que o prefixo desocorre no particípio de um verbo sem introduzir a pressuposição. Considere-se a frase a seguir:

(42) Essas ideias são desconectadas na cabeça de qualquer pessoa normal.

Aqui, não há pressuposição de que as ideias estavam previamente conectadas: o prefixo simplesmente nega um estado - “conectado" (as ideias são não-conectadas). O comportamento, 
portanto, é semelhante ao do prefixo em adjetivos como desleal. Isso quer dizer que, nesse caso, segundo a lógica da proposta defendida neste artigo, o prefixo toma todo o particípio, não o sintagma raiz dentro do particípio. Como o prefixo des- não faz seleção categorial na análise aqui apresentada, não há problema com o fato de ele tomar o particípio do verbo desde que este disponibilize uma variável de estado. Mas reconheço que o tema precisa de mais investigação, até porque pode ter implicações nas propostas de análise do prefixo nos particípios apresentadas em (31).

O quarto ponto de que gostaria de falar aqui já foi mencionado em dado momento do texto. Trata-se da ocorrência do prefixo des- em verbos como respeitar, obedecer, aconselhar, cumprir, conhecer etc. Como vimos, não se trata de verbos de mudança de estado do objeto direto, o que implica não haver estado alvo a ser pressuposto para o complemento - ou modificado pelo prefixo ${ }^{23}$. Tampouco aqui o prefixo é recursivo. Então, por que é licenciado nesses casos? É necessário fazer uma investigação específica para esse grupo de verbos, entender bem suas propriedades acionais, mas isso também fica para pesquisa futura. Curiosamente, o uso do prefixo re-nesses itens é degradado, idiomático ou simplesmente inaceitável. Penso que a investigação deva tomar essa complementaridade em conta.

Por fim, é preciso reconhecer que a explicação da distribuição dos prefixos dada no artigo, que é essencialmente semântica, esbarra no fato de que os prefixos não ocorrem ou são muito marginalmente aceitáveis em alguns verbos que, segundo a proposta, deveriam licenciálos. Tomem-se, por exemplo, predicados como "repegar o ônibus" ou "redar um presente para a namorada". Casos como esses precisam ser explicados, e creio que haja restrições de outra natureza em jogo aqui, que não criam maiores dificuldades para as propostas acima, mas essa investigação também fica para trabalhos futuros.

Agradecimentos: Agradeço à Janayna Carvalho, à Ana Clara Polakof, ao Filipe Hisao Kobayashi, ao Andrew Nevins e aos membros do GELin por comentários e sugestões. Os eventuais erros deste trabalho são de minha inteira responsabilidade.

MEDEIROS, Alessandro Boechat. Prefixes, recursiveness and the verbal phrase structure. Revista do GEL, v. 13, n. 1, p. 56-86, 2016.

\footnotetext{
${ }^{23}$ Note-se, ainda, que, como ocorre no ambiente nominal, a re-ocorrência do prefixo des- nesses verbos também é degradada.
} 
Abstract: The main purpose of this paper is to describe and explain the distribution of the Brazilian Portuguese prefixes re-and des-, their semantic and positional relations, when they co-occur and their insertion in the verbal phrase structure. The proposals here show that a syntactic decomposition of verbal phrase event structures allows a natural explanation for the properties presented and discussed in the initial sections of this paper. In the end, the paper discusses briefly the function of recursive prefixes in defining special meanings of roots.

Keywords: Recursive prefixes. Event structure. Roots. Categorizing morphemes. Distributed Morphology.

\section{Referências}

AlEXIAdOU, A.; ANAGNOSTOUPOUlOU, E. Structuring Participles. In: CHANG, C. B.; HAYNIE, H. J. (Org.). Proceedings of the 26th West Coast Conference on Formal Linguistics. Somerville, MA, 2008. p. 33-41.

ALEXIADOU, A.; ANAGNOSTOUPOULOU, E; LECHNER, W. Variation in repetitive morphemes: some implications for the clausal architecture. Trabalho apresentado no Workshop on the state of the art in comparative syntax, NYU, setembro de 2014.

BORER, H. Structuring sense. Oxford: Oxford University Press, 2005.

CAMARA JR., J. M. Dicionário de linguística e gramática. Petrópolis: Vozes, 1970.

CARDINALETTI, A. On the Italian prefix ri-: Incorporation vs. Cliticization. In: University of Venice Working Papers in Linguistics, v. 13, 2003

CHOMSKY, N. The Minimalist Program. Cambridge Mass: MIT Press, 1995.

Derivation by Phase. In: KENTOWICZ, M. (Org.). Ken Hale: A life in language. Cambridge, MA: MIT Press, p. 1-52, 2001.

DIKKEN, M. den. Relators and Linkers: The Syntax of Predication, Predicate Invertion, and Copulas. The MIT Press, 2006.

EMBICK, D. On the structure of resultative participles in English. Linguistic Inquiry, Cambridge, MA, v. 35, n. 3, p. 335-392, 2004.

Press, 2010.

Localism versus globalism in morphology and Phonology. Cambridge, MA: MIT

FOX, D. Antecedent-Contained Deletion and the Copy Theory of Movement. Linguistic Theory, v. 33, n. 1, p. 63-96, 2002.

GONÇALVES, C. A. Prefixação: derivação ou composição? Novos enfoques sobre uma antiga polêmica. Matraga, Rio de Janeiro, v. 19, n. 30, p. 142-167, 2012. 
HALE, K.; KEYSER, S. J. Prolegomena to a theory of Argument Structure. The MIT Press, 2002.

HALLE, M.; MARANTZ, A. Distributed morphology and the pieces of inflection. In: HALE, K.; KEYSER, S. (Org.). The view from building 20. Cambridge: MIT Press, 1993. p. 111176.

HOUAISS, A. Dicionário eletrônico Houaiss da língua portuguesa. São Paulo: Objetiva, 2009.

KEYSER, S. J.; ROEPER, T. Re: The Abstract Clitic Hypothesis. Linguistic Inquiry, Cambridge, MA, v. 23, n. 1, p. 89-125, 1992.

KRATZER, A. Building statives, 2000. Disponível em:

$<$ http://semanticsarchive.net/Archive/GI5MmI0M/kratzer.building.statives.pdf>. Acesso em: 18 abr. 2003.

LEBEAUX, D. Language acquisition and the form of the grammar. Tese de doutorado University of Massachussets, Amherst, 1988.

MARANTZ, A. Words. Handout não publicado, Cambridge, MA: MIT, 2001.

Restitutive re- and the first phase syntax/semantics of the VP. Handout não

publicado, Nova Iorque: New York University, 2007.

Locality Domains for Contextual Allomorphy across the Interfaces. In:

MATUSHANSKY, O.; MARANTZ, A. (Org.). Distributed Morphology Today:

Morphemes for Morris Halle. Cambridge Mass: MIT Press, 2013. p. 95-116.

MEIRELLES, L.; CANÇADO, M. Análise semântica do prefixo re- em verbos do português brasileiro. Revista da ABRALIN, v. 13, p. 155-180, 2014.

MEDEIROS, A. B. Para uma abordagem sintático-semântica do prefixo des-. Revista da ABRALIN, v. 9, n. 2, p. 95-121, 2010.

Considerações sobre o prefixo re-. Alfa, São Paulo, v. 56, n. 2, p. 583-610, 2012.

OLIVEIRA, S. M. Derivação Prefixal: um estudo sobre alguns prefixos do Português Brasileiro. 2004. 170 f. Dissertação (Mestrado em Linguística) - Centro de Comunicação e Expressão, Universidade Federal de Santa Catarina, Florianópolis. 2004.

PARSONS, T. Events in the semantics of English: a study in subatomic semantics. Cambridge, MA: MIT Press, 1990.

RIBEIRO, P. N. Revisitando a Semântica Conceitual de Jackendoff: um estudo sobre a semântica verbal no PB sob a perspectiva da Hipótese Locacional. 2014. 186 f. Tese (Doutorado em Linguística) - Instituto de Letras, Universidade Federal do Rio Grande do Sul, Porto Alegre, 2014. 
SCHWINDT, L. C. O prefixo no português brasileiro: análise prosódica e lexical. DELTA, São Paulo, v. 17, n. 2, p. 175-207, 2001. Disponível em:

$<$ http://www.scielo.br/scielo.php?script=sci_arttext\&pid=S0102-

44502001000200001\&lng=en\&nrm=iso>. Acesso em: 12 jun. 2015.

SILVA, M. C.; MIOTO, C. Considerações sobre a prefixação. ReVEL, v. 7, n. 12, 2009.

SPORTICHE, D. Re re again. In: BRUGÉ, L. et al. (Org.). Functional Heads: The

Cartography of Syntactic Structures. v. 7. Oxford University Press, New York, 2012.

STECHOW, A. The different readings of wieder 'again': a structural account. Journal of Semantics, Oxford, v. 13, n. 2, p. 87-138, 1996.

WILLIAMS, E. Telic too late. Handout não publicado, Cambridge, MA: Harvard University, 2006.

Submetido em 29/05/2015

Aceito em 11/01/2016 